\title{
Materials for Restoration of Bone Tissue
}

\author{
Anna A. Shumilova ${ }^{\text {a* }}$ and Ekaterina I. Shishatskaya ${ }^{a, b}$ \\ ${ }^{a}$ Siberian Federal University \\ 79 Svobodny, Krasnoyarsk, 660041, Russia \\ ${ }^{b}$ Institute of Biophysics SB RAS \\ 50/50 Akademgorodok, Krasnoyarsk, 660036, Russia
}

Received 11.04.2014, received in revised form 21.05.2014, accepted 31.05.2014

Reconstruction and optimization of the process of healing of bone tissue defects using new materials and technologies is an urgent problem in medicine. This is due to a high level of orthopedic traumas and prevalence of dental and other socially significant diseases of bone tissue, leading to the dramatic incapacitation of population and accompanied by huge financial costs. This review analyzes the published data on osteoplastic materials for bone reconstructive surgery from traditional allo- and xenografts, titanium alloys, calcium phosphates and bioceramics to modern materials based on biocompatible and biodegradable polymers; the results obtained by the SFU Laboratory of New Biomaterials Biotechnology are presented.

Keywords: reconstructive surgery, bone tissue, osteoplastic materials, implants, biocompatibility, biodegradation, polyhydroxyalkanoates.

\section{Материалы для восстановления костной ткани}

\author{
А.А. Шумилова а, Е.И. Шишацкая а, \\ ${ }^{a}$ Сибирский федеральный университет \\ Россия, 660041, Красноярск, пр. Свободный, 79 \\ ${ }^{6}$ Институт биофизики СО РАН \\ Россия, 660036, Красноярск, Академгородок, 50/50
}

Реконструкция и оптимизация процесса заживления дефектов костной ткани с помощью новых материалов и технологий является актуальной проблемой в медицин. Обусловлено это высоким уровнем травм опорно-двигательного аппарата и распространенностью стоматологических и других социально значимых заболеваний костной ткани, что приводит

(C) Siberian Federal University. All rights reserved

* Corresponding author E-mail address: shumilova.ann@mail.ru 
$\kappa$ катастрофической потери трудоспособности населения и сопровождается огромными материальными затратами. В настоящем обзоре анализируются литературные данные о костно-пластических материалах для реконструктивной хирургии костной ткани от традиционных алло- и ксенотрасплантатов, титановых сплавов, фосфатов кальиия, биокерамики до современных материалов на основе биосовместимых и биоразрушаемых полимеров и представлены результаты, полученные коллективом лаборатории биотехнологии новых биоматериалов СФУ.

Ключевые слова: реконструктивная хирургия, костная ткань, костно-пластические материалы, имплантаты, биосовместимость, биодеградация, полигидроксиалканоаты.

\section{Потребность хирургии}

\section{в костно-пластических материалах}

Восстановление костных дефектов, возникающих в результате травм, воспалительных процессов, после удаления новообразований и оперативных вмешательств, является актуальной проблемой для реконструктивной хирургии. Количество операций, проводимых с использованием костных трансплантатов и имплантатов, постоянно увеличивается, вызывая высокий спрос на современные материалы и технологии. Ежегодно только в Европе осуществляется около 400000 операций по восстановлению костных дефектов и более 600000 в США (Hing et al., 2004; Parikh et al, 2012). Согласно годовому отчету компании «ORTHOWORLD», крупнейшему производителю ортопедических изделий, мировые продажи имплантатов уже превысили 43,1 млрд дол. в 2012 г., увеличившись на 15 млрд дол. по сравнению с 2002 г. (Orthoworld Inc., 2012; Clinica Reports, 2002). Так, только в США расходы на костные имплантаты в 2010 г. достигли 1,3 млрд дол. с прогнозируемым темпом увеличения к 2017 г. на 7,4 \%, что составит около 2,2 млрд дол. (Orthoworld Inc., 2011). Если говорить о потребности отечественного рынка, то согласно прогнозу продажи кост- ных имплантатов в России к 2015 г. составят порядка 6,5 млрд руб. (Российский рынок имплантатов для остеосинтеза в 2005-2012 годах. Прогноз до 2017 года, 2012). По данным Минздравсоцразвития России, ежегодно в нашей стране травмы получают около 15 млн человек, $70 \%$ из них - это пожилые люди. Следует иметь в виду, что почти 90 \% всех переломов костей приходится на опорно-двигательный аппарат; число больных, нуждающихся в лечении, составляет свыше $60 \%$. Частота поражения костей скелета злокачественными опухолями составляет $3 \%$ в структуре всех новообразований человека, из них 70 \% локализуется в области суставов. По данным отечественных и зарубежных авторов, около 1-1,5 \% населения страдают ревматоидными формами поражения суставов и около $15-80 \%$ населения в возрасте 20-80 лет имеют дегенеративные формы заболевания. Общая потребность в операциях по эндопротезированию суставов в России составляет около 300000 в год (в среднем 27 операций на каждые 10000 жителей РФ), реально выполняются около 50000 (Анализ рынка и потребности суставных имплантатов, 2012).

В связи с высокой частотой рецидивов и низкой удовлетворённостью результатами 
традиционного лечения разработка новых и усовершенствование уже существующих имплантатов становятся первостепенной задачей медицины, биологии, биотехнологии.

В клинической практике проблему восстановления дефектов костной ткани в последние годы пытаются решить путем разработки и внедрения новых методик реконструктивных операций с использованием материалов, восполняющих утраченный объем кости, и факторов, улучшающих ее репаративные свойства. В нормальных условиях основная часть репаративных процессов костной ткани происходит за счет остеобластов надкостницы, которые проникают в зону перелома и восстанавливают целостность кости. Несмотря на достаточно активную способность к репарации, костная и хрящевая ткань иногда не в состоянии полностью устранить дефицит тканей, возникший в результате действия повреждающего фактора, что является серьезной проблемой в реконструктивной ортопедии.

\section{Характеристика}

\section{костно-пластических материалов}

Практический опыт, накопленный клиницистами в области челюстно-лицевой хирургии и травматологии, показывает, что использующиеся в настоящее время остеопластические материалы имеют как свои достоинства, так и недостатки. Именно поэтому необходим поиск новых материалов - заменителей костной ткани, обладающих следующими преимуществами: относительной простотой проведения хирургического вмешательства, расширением возможности моделирования, стабильностью структуры, высокой механической прочностью, биосовместимостью, остеокондуктивными и остеоиндуктивными свойствами, отсутствием инфекционных возбудителей, способностью резорбироваться в организме без образования токсичных продуктов по мере восстановления новых тканей в месте дефекта и т. д. (Baino, 2011).

Попытки восстановить утраченную часть кости или хряща предпринимались с давних пор и сводились, прежде всего, к ауто- и аллотрансплантации или использованию синтетических материалов. При этом наиболее пригодными для трансплантации и последующей биоинтеграции являются аутотрансплантаты, которые готовятся из собственных тканей пациента и этим полностью исключают основные иммунологические и большинство инфекционных осложнений при последующей пересадке. Преимущественно аутотрансплантаты получают с таких донорских мест, как свод черепа, нижняя челюсть, ребра, теменная кость и гребень подвздошной кости (Baino, 2011). Однако при такой имплантации проблемы возникают уже из-за увеличения времени хирургического вмешательства и, соответственно, нахождения пациента под общим наркозом (Chowdhury, 1998). Кроме того, такая операция не исключает дополнительные костные дефекты у пациента.

Альтернативным решением восполнения донорского материала для костной пластики является использование аллотрансплантатов (часто называемых гомотрансплантатами), мягких и жестких тканей от другого пациента или трупа (Schlickewei et al., 2007; Courtney et al., 2000). Преимуществами такого имплантационного материала выступают снижение времени операции, возможность заготовки и моделирования имплантата и практически неограниченное наличие прививаемого материала. Недостатки костных алло- и ксенотрансплантатов: медленная остеоинтеграция, риск передачи от донора к реципиенту различных заболеваний, возможность развития реакции гистонесовместимости и хронического гранулематозного воспаления, высокая стои- 
мость аллокости, религиозные ограничения. Использование аллогенного материала предполагает подготовку свежезамороженных, лиофилизированных, деминерализованных, формализованных и малодифференцированных костных тканей непосредственно перед трансплантацией или требует наличия в клинике банка для хранения такого материала, что из-за высоких затрат доступно только очень крупным медучреждениям. Для минимизации рисков алло- и ксенотрансплантаты подвергают интенсивной обработке, что уменьшает остеоиндуктивные свойства и механическую прочность этих трансплантатов почти на 50 \%, хотя риск инфицирования реципиента всё-таки полностью не устраняется (Campbell et al., 1999). Кроме того, подготовка костно-пластических ксеноматериалов требует специализированных процедур забора тканей и строгого отбора животных для обеспечения безопасности реципиентов, а также процедур химической и физической обработки, что сказывается на стоимости и доступности таких материалов.

Значительную роль в ортопедии и травматологии играют металлы. Однако применение при лечении переломов трубчатых костей металлических аппаратов внешней фиксации (АВФ), крепежных элементов в виде винтов, спиц и стержней требует повторного хирургического вмешательства для удаления в случае достижения выздоровления пациента и не свободно от возникающих осложнений (металлозы, аутоиммунные реакции, асептическое воспаление, выделение из металлической конструкции токсических лигирующих компонентов - никель, хром и др.). В результате возникает индивидуальная непереносимость, остеопороз, остеолизис, нестабильность фиксации имплантата. К тому же высокая стоимость титановых имплантатов ограничивает их доступность (Hughes et al., 2003; Schon et al., 2006). Так, отечественная конверсионная фирма «Конмет» и зарубежная «Straiker» предлагают титановые пластины для пластики нижней стенки орбиты ценой более 5000 руб. и 20000 руб. К мембранным пластинам этой группы относятся также «Теф Ген» (Tef Gen), производимые компанией «Lifecore Biomedical» (США), цена этих зарубежных аналогов на 30 \% выше отечественных.

Использование для реконструкции дефектов кости искусственных материалов, идентичных минеральному компоненту костного вещества, привлекает пристальное внимание клиницистов. Кальций-фосфатные материалы, в т. ч. гидроксиапатит и его композиции с другими материалами в виде порошков, гранул, микрочастиц, пластин и т.п., а также в виде композиции с различными веществами, получили широкое распространение в стоматологической практике. В настоящее время для замещения костных дефектов в хирургической стоматологии, ортопедии и травматологии используют много различных сортов гидроксиапатита, отличающихся по форме и величине частиц. Считается, что искусственно полученный гидроксиапатит по химическому составу и кристаллографическим показателям практически идентичен гидроксиапатиту нативной кости (Parsons, 1988). Многими авторами и экспериментально, и клинически доказано, что использование гидроксиапатита имеет значительные преимущества перед другими имплантационными материалами. Его положительными характеристиками являются такие показатели, как легкость стерилизизации, продолжительный срок хранения, высокий уровень биосовместимости и медленная резорбция в организме (Воложин и др., 1993). Одним из недостатков данных материалов в качестве имплантатов при замещении костных дефектов признана низкая резорбция, что приводит к «замуро- 
выванию» имплантированного материала на стадиях in vivo или очень длительному процессу восстановления костной ткани - более 1-2 лет, а также низкие остеоиндуктивные свойства (Сергеева и др., 2007).

К современным материалам последнего поколения следует отнести и биоактивные стеклокристаллические материалы, состоящие из стекловидной матрицы и микрокристаллов, разработка которых велась биоматериаловедами (Кирилова и др., 2011). Опубликовано множество сообщений об успешном применении синтетических костно-пластических материалов, таких как сульфат кальция, биоактивное стекло, эфиры цианакриловой кислоты, полиакриламидный гель, трикальцийфосфат, препараты на основе альгината натрия и др. Разрабатываются и исследуются пористые стеклокристаллические (ситалловые) биоимплантаты; ряд препаратов рекомендован для клинических испытаний. Применяемая в стоматологической практике биокерамика и биокомпозиционные (кальцийфосфатные) материалы: марки «Interpore-200» и «Interpore-500» «Calcitite-2040», «Ostrix $\mathrm{NR}$ » (США), «Ceros-80» (Швейцария), «Osprovit 1,2» (Германия), «БАК-1000» (Россия), «Bioapatite» (Франция) сочетают в себе как биологическую активность, так и достаточную механическую прочность (Волова и др., 2009). Однако этим материалам, хорошо зарекомендовавшим себя в практике стоматологии, присуще свойство остеокондукции, но при этом до сих пор не доказано обладание ими такого необходимого свойства, как остеоиндукция, что делает их малопригодными для реконструкции больших костных дефектов.

После признания способности коллагена стимулировать регенерацию костной ткани этот материал получил широкое распространение. Однако сам по себе коллаген не подходит для восстановления больших костных дефектов, так как скорость его биорезорбции значительно выше, чем восстановление костной ткани. Поэтому были начаты исследования биокомпозиционных материалов, содержащих одновременно коллаген и гидроксиапатит. В настоящее время на рынке представлено много коммерческих препаратов для челюстно-лицевой хирургии и хирургической стоматологии зарубежных производителей «Alveloform» и «Bigraft», содержащих очищенный фибриллярный кожный коллаген и частицы гидроксиапатита (фирмы «Collagen Corp.», «Palo Alto», США) (Волова и др., 2009). Серия таких гибридных материалов создана и в России, это «Гидроксиапол», «КоллапАн®» - композиты гидроксиапатита и коллагена в виде гранул, пластин и гелей, в том числе наполненные антибиотиками, разработанные фирмами «Интермедапатит», «Росдент», «Полистом»; биоактивный гранулированный остеопластический материал «Биальгин®» на основе аморфного, нанодисперсного (5-10 нм), полностью резорбируемого гидроксиапатита кальция, включенного в полисахаридную матрицу альгината натрия (Шишацкий, Шишацкая, 2010). Разработаны эффективные новые остеопластические материалы для хирургической стоматологии и челюстно-лицевой хирургии серии «Остеопласт®» Научно-производственной компанией «Витаформ» на основе деминерализованного и недеминерализованного костного коллагена и гликозаминогликанов (сГАГ); «Конектбиофарма» и тканевый банк ЦИТО им. Н.Н. Приорова совместно разработали биокомпозиционный материал на основе костного коллагена и гидроксиапатита, полученных из костной ткани животных (телята и свиньи) с выделенными сГАГ (Панасюк и др., 2000). Однако относительно низкие прочностные характеристики этих материалов и 
довольно быстрая биорезорбция в организме не позволяют использовать такие композитные материалы для реконструкции крупных и долго восстанавливающихся дефектов костной ткани.

Попытка создания композитов гидроксиапатита с синтетическими полимерными материалами (полиэтиленом, политерефталатом) оказалась не совсем удачной, несмотря на хорошие механические характеристики (модуль Юнга, прочность на сжатие, растяжение и изгиб), так как значительно снижается биосовместимость самого гидроксиапатита.

Существенный прогресс в области остеопластических материалов связан с получением композитных полимерных материалов, имитирующих взаимодействие минеральной части и коллагеновой матрицы костной ткани, синтезированных из природных полиэфиров (молочной, гликолевой и других кислот), способных к биодеградации и биорезорбции.

В настоящее время наиболее перспективными считаются биоразрушаемые полиэфиры монокарбоновых кислот, таких как полилактиды, полигликолиды, полигидроксиалканоаты и т. д. Эти полиэфиры, при свойственном им высоком уровне биосовместимости, распадаются в организме и в окружающей среде на безвредные фрагменты, метаболизирующиеся в конечном случае до воды и углекислого газа, а в некоторых случаях сами являются естественными метаболитами организма (Volova, 2006). Наиболее освоенные полиэфиры монокарбоновых кислот - полилактиды (ПМК) и полигликолиды (ПГК), которые с 1970 г. разрешены United States Food and Drug Administration (FDA) для использования в медицине в США. Полилактид получают ферментативным брожением сахаров или химическим синтезом и далее подвергают химической полимеризации. В связи с отсутствием термопластичности и растворимостью в водных средах полилактид используют в основном с гликолидом, их сополимеры получают ионной полимеризацией и сополимеризацией (Шишацкая, 2013). Однако этот процесс требует чрезвычайно высокой степени очистки мономера, поскольку только в данном случае удается получить полимеры с высокой молекулярной массой, необходимой для создания изделий с требуемыми характеристиками. Так, коммерчески доступные биосовместимостимые винты Bionx BioSorb $\mathrm{PDX}$ на основе поли-L-лактид-ко-гликолида, содержащего 85 \% L-лактида и 15 \% гликолида, были протестированы на модели дефекта черепа кроликов, в качестве контроля использовали титановые винты Stratek Medical AG. Оба типа винтов были установлены в черепе кролика по одному с каждой стороны сагиттального шва. Длина винтов составила 2 мм, а диаметр - 1,2 мм. Послеоперационное лечение достигло 72 недель. Макроскопически прооперированное место зажило у всех животных. Однако по микроскопическим данным была выявлена более сильная реакция отторжения на винты PLGA по сравнению с титановыми винтами, о чем свидетельствовало образование капсулы и постепенное ее утолщение в случае с винтами на основе полилактида и полигликолида.

\section{Потенциал \\ полигидроксиалканоатов}

На втором месте по значимости для биомедицинских применений и активности изучения находятся биоматериалы (полимеры) микробиологического происхождения - полимеры $\beta$ - и $\gamma$-гидроксимасляной кислот и сополимеры $\beta$-гидроксимасляной с другими монокарбоновыми кислотами (валериановой, гексановой), которые относятся к классу перспективных природных биоматериалов, так 
называемых полигидроксиалканоатов (ПГА) (Волова и др., 2010). В отличие от полилактидов полигидроксиалканоаты термопластичны, имеют более высокие прочностные характеристики, не растворяются в водных средах, поэтому сроки их биодеструкции более длительны; продукт распада этого полимера $\beta$-гидроксимасляная кислота, не вызывает такого резкого закисления тканей, как молочная кислота.

ПГА представляют большой интерес для ортопедии и травматологии в связи с их абсолютной биосовместимостью, медленной биодеградацией и высокой механической прочностью (Rai et al., 2011). Несмотря на то что эти полимеры исследуются сравнительно недавно, с конца 80-х - начала 90-х гг. XX столетия, наиболее активно - с 2000 гг., несомненным достижением последних лет (2010-2011 гг.) стало решение FDA о допуске ряда изделий фирмы «Терһа» для применения в клинической практике (Шишацкая и др., $2010,2013)$. Доказано, что биорезорбция матриксов и изделий из ПГА in vivo реализуется гуморальным и клеточным путями с участием макрофагов и гигантских клеток инородных тел с высокой активностью клеточной и сывороточной кислой фосфатазы, количество которых зависит от химической структуры полимера, формы и места имплантации изделия (Николаева и др., 2011).

Из алифатических полиэфиров класса полигидроксиалканоатов наиболее изучен поли3-гидроксибутират (ПЗГБ), биосовместимость и способность к медленной биодеградации которого доказана отечественными и зарубежными учеными (Gredes et al., 2014). В последние годы область применения ПЗГБ стала разнообразной: от медицинских имплантатов, мембран, пластин, клеточных носителей для тканевой инженерии к активному развитию новых систем доставки лекарственных пре- паратов. Биосовместимые и остеоиндуктивные свойства ПЗГБ и композитов на его основе доказаны в ряде работ по восстановлению костных дефектов у лабораторных животных (Luklinska, 2003; Schluckwerder, 2003; Carlo, Borges, 2009; Alves et al., 2011). Способность ПЗГБ матриксов поддерживать остеогенез в месте имплантации продемонстрирована в работе Claudia Rentsch и Barbe Rentsch (2009), где авторами был исследован остеогенный потенциал и васкуляризация тканево-инженерных 3D-матриксов ПЗГБ на модели костного дефекта диафиза большеберцовой кости крыс. Эти же свойства ПЗГБ были доказаны в работе Tomasa Gredes (2014) в эксперименте по восстановлению дефекта черепа крыс, где уже на пятой неделе после имплантации ПЗГБ было отмечено формирование новообразованной костной ткани. В работе (Reis et al., 2010) были исследованы остеоиндуктивные и остеокондуктивные свойства композитного матрикса на основе 25 \% гидроксиапатита и 75 \% ПЗГБ. Согласно гистологическим исследованиям в препаратах ПЗГБ отмечена новая губчатая ткань в медуллярной области, между композитом и кортикальной костью, наблюдается соединительная ткань и новая васкуляризованная губчатая кость без воспалительного инфильтрата, в полной мере подтверждающие биосовместимость композита. Способность поддерживать пролиферацию клеток остеобластического ряда продемонстрирована композитными матриксами на основе ПЗГБ с гидроксиапатитам и биокерамикой. Установлено, что композиты на основе ПГБ/Bioglass способны поддерживать клеточную пролиферацию культуры клеток остеобластов MG-63 и формирование in vivo кальций-фосфатных образований (Misra et al., 2010). На примере композитов на основе ПГА и волластонита прототипов имплантатов для реконструктивного остеогенеза - была изучена способность 
поддерживать клеточную адгезию клеток остеобластического ряда.

Следующий представитель полимеров этого класса сополимер поли-3гидроксибутирата-3-гидроксивалериата также нашел свое практическое применение в инженерии костной ткани. В серии работ доказано, что в течение нескольких месяцев после имплантации ПГБ-со-ПГВ в костный дефект большеберцовой кости лабораторным животным происходит постепенное уменьшение массы имплантированного матрикса и формирование новообразованной костной ткани в порах матрикса (Köse, 2003a, 2003b).

Способность поддерживать пролиферацию аллогеных хондроцитов и регенерацию суставного хряща кролика исследована на 3D-матриксах из поли(3-гидроксибутиратасо-3-гидроксигексаноата). Доказано, что после 16 недель имплантации в порах матриксов наблюдается формирование вновь образованной хрящевой ткани (You et al., 2011; Wang et al., 2008).

Биосовместимые и резорбируемые свойства этого класса полимеров вызвали мировой интерес многих ученых, что доказано резким увеличением числа научных публикаций в Китае, Южной Корее, Японии, Индии, Бразилии и России. В нашей стране отмечено небольшое количество коллективов, занимающихся изучением ПГА: это Институт микробиологии РАН, Институт физиологии и биохимии микроорганизмов РАН (Пущино), Институт биохимии им. А.Н. Баха РАН и Центр новых медицинских технологий Института химической биологии и фундаментальной медицины (г. Новосибирск). Однако наиболее активно и успешно изучением ПГА в качестве костнопластических материалов в настоящее время в России занимается коллектив учёных на базе Института биофизики СО РАН, где разработана технология синтеза полимеров различной химической структуры и изучены их физико-химические и медикобиологические свойства, и Института фундаментальной биологии и биотехнологии Сибирского федерального университета, лаборатории биотехнологии новых материалов СФУ под руководством Т.Г Воловой и Е.И. Шишацкой. Зарегистрирована марка материала и изделий «Биопластотан».

С использованием высокоочищенных образцов полимеров, находящихся в различных фазовых состояниях, сконструированы прессованные пластины, макро- и микропористые объемные имплантаты, пломбировочный материал, клеточные носители и композитные изделия для костной пластики (рис. 1).

Биологическая совместимость матриксов всех типов доказана при прямом контакте в культурах клеток и подтверждена in vivo на уровне клеточного ответа, реакции крови и местной реакции тканей при имплантации образцов подкожно, внутримышечно, в модельные дефекты костной ткани. Ответная реакция тканей однотипна и характеризуется непродолжительным посттравматическим воспалением без образования выраженных фиброзных капсул и иных неблагоприятных реакций, включая реакцию системы крови, состояние периферических органов, иммунитета и др.

Исследованы физико-химические и физико-механические свойства плотных и пористых композитов из полигидроксибутирата (ПЗГБ) и гидроксиапатита (ГАП) с различным соотношением компонентов, а также волластонитом, полученных различными методами. В экспериментах на животных показано, что композит полимера с ГАП обладает остеокондуктивными свойствами и способствует образованию костной ткани в тесте эктопического костеобразования. В многочисленных участках, прилежащих к имплан- 

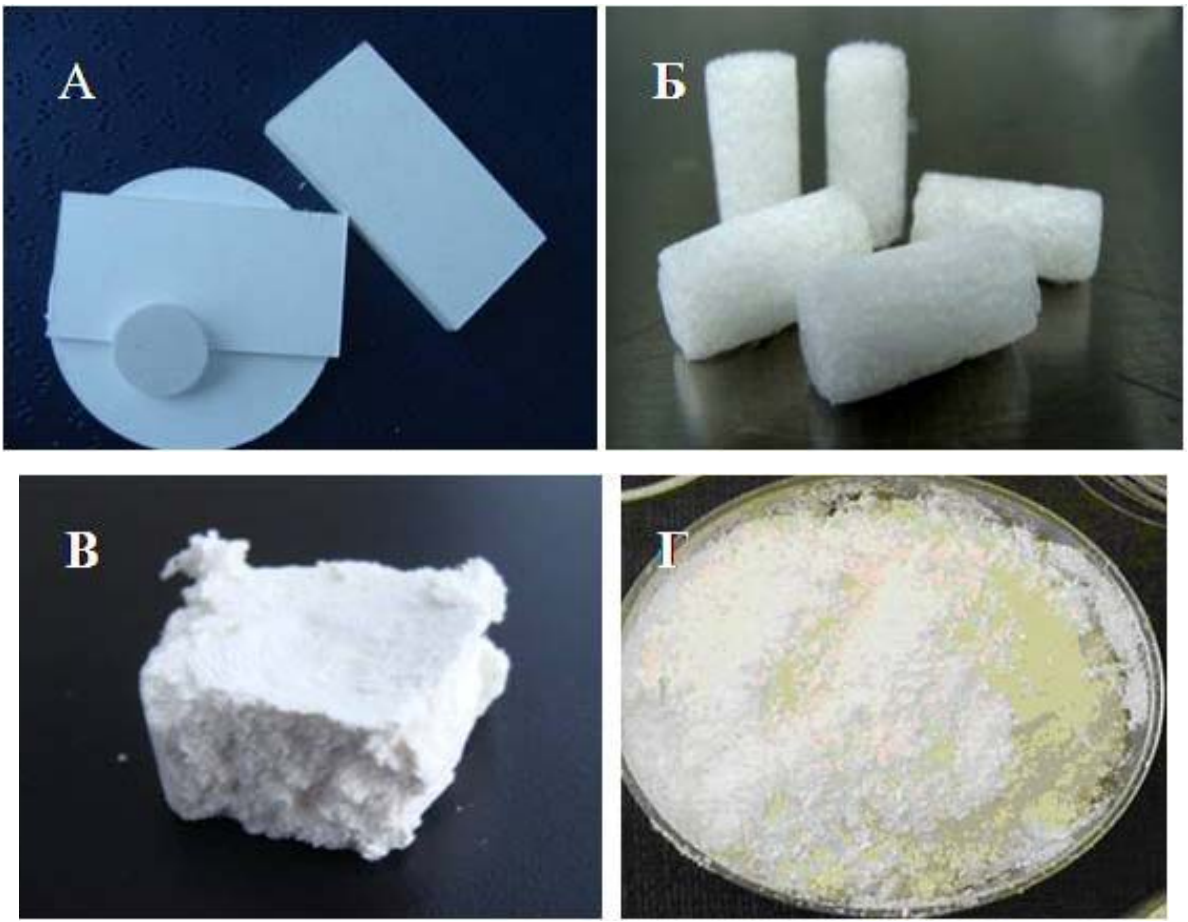

Рис. 1. Серия изделий на основе ПГА для восстановления костных дефектов: А - прессованные пластины; Б - макропористые объемные имплантаты; В - объемные имплантаты, полученные лиофилизацией; Г - пломбировочный материал

татам, отмечено формирование костной ткани, выявлены разнообразной величины и формы участки остеоидной ткани, образующие как отдельные островки, так и ячейки, в которых располагались паренхиматозные (костного мозга) и стромальные клетки (Shishatskaya et al., 2006).

Сконструировано и охарактеризовано семейство опорных клеточных носителей в виде мембран из резорбируемых ПГА четыpex типов: гомополимер 3-гидроксимасляной кислоты, сополимеры 3-гидроксимасляной и 4-гидроксимасляной кислот, 3-гидроксимасляной и 3-гидроксивалериановой кислот, 3-гидроксимасляной и 3-гидроксигексановой кислот. По результатам окрашивания культивируемых клеток мыши линии NIH 3T3 флуоресцентным зондом на ДНК DAPI и в МТТ-тесте выявлено, что все представленные типы ПГА не проявляют цитотоксичности при прямом контакте с клетками, обладают высокой биосовместимостью; по адгезивным свойствам и способности поддерживать пролиферацию фибробластов сопоставимы с полистиролом и превосходят полимолочную кислоту (Николаева, 2011).

На модели сегментарной остеотомии исследованы остеопластические свойства разработанных имплантатов в сравнении с фирменными материалами, применяемыми в стоматологии (композитом гидроксиапатит/ коллаген, препаратом «Коллапол®» и препаратом аллокости «Bio-OSS $(»)$. Доказано, что все типы имплантатов, содержащих в качестве основного компонента поли-3гидроксибутират, обладают остеоиндуктивными свойствами и индуцируют остеогенез (Камендов и др., 2008). На животных с экспериментальной формой хронического остеомиелита установлено, что пломбировочный 
материал из смеси ПЗГБ/тиенам пригоден для пластики костных полостей, инфицированных Staphylococcus aureus. Заполнение инфицированных костных дефектов длинных трубчатых костей после хирургической обработки гидрофобным пломбировочным материалом из ПЗГБ и смеси ПЗГБ/тиенам обеспечивает подавление инфекции, более быстрое восстановление костных дефектов и раннее восстановление опорных свойств оперированной конечности по сравнению с контролем (препарат аллокости) (Шишацкая и др., 2012; 2013). Эффективность применения поли-3-гидроксибутирата исследована на модели костного дефекта нижней стенки глазной орбиты кроликов. Доказано, что применение исследуемого биосовместимого полимерного материала приводит к значительно более быстрому заживлению послеоперационных кожных ран, менее выраженной воспалительной реакции на имплантат и более раннему восстановлению костной структуры нижней стенки орбиты по сравнению с ксенотрансплантатом. На примере культуры фибробластов и мультипотентных мезенхимальных стволовых клеток (ММСК) крыс показана способность полимерных носителей из резорбируемого полиэфира сополимера 3- и 4-гидроксипроизводных масляной кислоты поддерживать рост и деление культивируемых клеток в клетки остеобластического ряда. Последнее подтверждено детектированием в культуре клеток внеклеточных преципитатов кальция, активностью щелочной фосфатазы и продукцией остеопонтина (Шишацкая и др., 2013).
Ценные медико-биологические свойства данного класса полимеров, прежде всего биосовместимость ибиодеградация, разнообразие состава, вариабельность физико-химических и технологических свойств определяют реальные и потенциальные возможности использования данного материала в костной пластике.

\section{Заключение}

Несмотря на широкий выбор остеопластических материалов, представленных в настоящее время аллогенными и ксеногенными трансплантатами, ортофосфатами кальция, коллагеном, полисахаридами и другими биополимерами, многие из них имеют ряд существенных недостатков, что негативно отражается на сроках и качестве восстановления костных дефектов и, соответственно, ограничивает их широкое применение в костной практике. Однако большие надежды в данной области возлагаются на биосовместимыме полимеры с заданными сроками биодеградации, к которым относятся полиэфиры гидроксикарбоновых кислот - полигидроксиалканоаты (ПГА). Благодаря высокой биологической совместимости, длительным и управляемым скоростям разрушения, механической прочности и способности перерабатываться в различные специализированные изделия, новые остеопластические имплантаты, сконструированные на основе ПГА, будут отвечать всем требованиям современной реконструктивной хирургии.

\section{Список литературы}

1. Анализ рынка и потребности суставных имплантатов. (2012) BMTechnology. http://www. bmte.ru/content/analiz-rynka-i-potrebnosti-sustavnyh-implantatov

2. Воложин С.А. (1993) Реакция периодонта на пломбирование каналов корней зубов гидроксиапатит содержащей пастой. Актуальные вопросы экспериментальной и клинической медицины. 5: 4. 
3. Волова Т.Г., Шишацкая Е.И., Миронов П.В. (2009) Материалы для медицины, клеточной и тканевой инженерии [Электронный ресурс]: электрон. учеб. пособие / - Электрон. дан. (6 Мб). - Красноярск.

4. Волова Т.Г., Шишацкая Е.И., Шишацкий О.Н. (2010) Биосовместимые полимеры. Наука в России. 1: 4-8.

5. Камендов И.В., Старосветский С.И., Шишацкая Е.И., Волова Т.Г. (2008) Морфологический особенности остеогенеза с применением биополимера из полигидроксибутирата и его композиций. Институт стоматологии. 2: 92-93.

6. Кирилова И.А., Садовой М.А., Подорожная В.Т. (2012) Сравнительная характеристика материалов для костной пластики: состав и свойства. Хирургия позвоночника. 3: 72-83.

7. Николаева Е.Д., Шишацкая Е.И., Мочалов К.Е., Волова Т.Г., Сински Э.Дж. (2011) Сравнительное исследование клеточных носителей, полученных из резорбируемых полигидроксиалканоатов различного химического состава. Клеточная трансплантология и тканевая инженерия. 4: 63-67.

8. Панасюк А.Ф., Ларионов Е.В. (2000) Хондроитинсульфаты и их роль в обмене хондроцитов и межклеточного матрикса хрящевой ткани. Научно-практическая ревматология. 2: 46-55.

9. Российский рынок имплантатов для остеосинтеза в 2005-2012 годах. Прогноз до 2017 года. (2012) ABERCARDE Consulting. http://www.abercade.ru/research/reports/9863.html

10. Сергеева Н.С., Ахмедова С.А., Гольдберг М.А., Чиссов В.И., Смирнов В.В., Баринов С.М., Свиридова И.К., Кирсанова В.А. (2007) Композиционный материал на основе гидроксиапатита и карбоната кальция для заполнения костных дефектов при реконструктивнопластических операциях. Патент (RU) № 02429885 C1.

11. Шишацкий О.Н., Шишацкая Е.И. (2010) Анализ рынка материалов и изделий медицинского назначения. Красноярск: Красноярский писатель, 144 с.

12. Шишацкая Е.И., Волова Т.Г. (2010) Полигидроксиалканоаты как матрикс в клеточных технологиях. Клеточная трансплантология и тканевая инженерия. 3: 55-56.

13. Шишацкая Е.И., Николаева Е.Д., Горева А.В., Бригкхам К.Д., Волова Т.Г., Синкси Э.Д. (2012) Исследование пленочных матриксов из резорбируемых полигидроксиалканоатов различного химического состава in vivo: реакция тканей и кинетика биоразрушения. Клеточная трансплантология и тканевая инженерия. 1: 73-80.

14. Шишацкий О.Н., Шишацкая Е.И., Волова Т.Г. (2010) Разрушаемые полимеры: потребности, производство, применение. Красноярск: «ООО НИТ», 156 с.

15. Шишацкая Е.И., Камендов И.В., Старосветский С.И., Винник Ю.С., Маркелова Н.М., Шагеев А.А., Шумилова А.А. (2013) Исследование остеопластических свойств резорби-руемого поли-3-гидроксибутирата in vivo на моделях хронического остеомиелита. Врач-аспирант. $1(56): 127-132$

16. Шишацкая Е.И., Камендов И.В., Старосветский С.И., Винник Ю.С., Маркелова Н.М., Шагеев А.А., Шумилова А.А. (2012) Исследовнаие остеопластических свойств резорбируемого поли-3-гидроксибутирата in vivo на модели сегментарной. Креативная хирургия и онкология. 4: 48-52.

17. Шишацкая Е.И., Николаева Е.Д., Шумилова А.А., Шабанов А.В., Волова Т.Г. (2013) Культивирование мультипотентных мезенхимальных стромальных кле-ток костного мозга на

$$
-219-
$$


носителях из резорбируемого Биопластотана. Клеточная трансплантология и тканевая инженерия. 1: 57-65.

18. Alves E, Rezende C. (2011). Orthopedic implant of a polyhydroxybutyrate (PHB) and hydroxyapatite composite in cats. J. of Fel. Med. and Surg. 13: 546-552.

19. Baino F. (2011) Biomaterials and implants for orbital floor repair. Acta Biomaterialia. 7: 32483266.

20. Campbell D.G., Li P. (1999) Sterilization of HIV with irradiation: relevance to infected bone allografts. Aust. NZ. J. Surg. 69: 517-521.

21. Chowdhury K, Krause G.E. (1998) Selection of materials for orbital floor reconstruction. Arch. Otolaryngol. Head. Neck. Surg. 124: 1398-1401.

22. Courtney D.J., Thomas S, Whitfield P.H. (2000) Isolated orbital blowout fractures: survey and review. Br. J. Oral. Maxillofac. Surg. 38: 496-503.

23. Clinica Reports (2002) Orthopaedics: key markets and emerging technologies, report no. CBS905E, PJB Publications Limited.

24. CarloE, Borges A. (2009). Comparison of in vivo properties of hydroxyapatite-polyhydroxybutyrate composites assessed for bone substitution. J. of Craniof. Surg. 20: 853-859.

25. Gredes T., Gedrange T., Claudia Hinüber C., Gelinsky M., Kunert-Keil C. (2014) Histological and molecular-biological analyses of poly(3-hydroxybutyrate) (PHB) patches for enhancement of bone regeneration. Annals of Anatomy. (in press)

26. Hing K.A. (2004) Bone repair in the twenty-first century: biology, chemistry or engineering? Phil. Trans. R. Soc. Lond. A. 362: 2821-2850.

27. Hughes C.W., Page K, Bibb R, Taylor J, Revington P. (2003) The custom-made titanium orbital floor prosthesis in reconstruction for orbital floor fractures. Br. J. Oral. Maxillofac. Surg. 41: 50-53.

28. Köse G, Kenar H, Hasirci N. et al. (2003 a). Macroporous poly(3-hydroxybutyrate-co-3hydroxyvalerate) matrices for bone tissue engineering. J. Biomaterials. 24: 1949-1958.

29. Köse G.T., Ber S, Korkusuz F, Hasirci V. (2003 b). Poly(3-hydroxybutyric acid-co-3-hydroxyvaleric acid) based tissue engineering matrices. J. of Mater. Sci. 14: 121-126.

30. Luklinska Z.B., Schluckwerder H. (2003) In vivo response to HA - polyhydroxybutyrate / polyhydroxyvalerate composite. J. of Micros. 2: 121-129.

31. Misra S, Ansari T, Valappil S, Mohn D, Philip S, Stark W, Roy I, Knowles J, Salih V, Boccaccini A. (2010) Poly(3-hydroxybutyrate) multifunctional composite scaffolds for tissue engineering applications. J. Biomat. 31: 2806-2815.

32. Orthoworld Inc (2011)., Orthopaedic Industry Annual Report.

33. Orthoworld Inc (2012)., Orthopaedic Industry Annual Report.

34. Parsons J. (1988) Bioceramics: Materials Characteristics Versus. Ann. N Y Acad. Scienc. 523: 190.

35. Parikh S.N. (2002) Bone graft substitutes in modern Orthopedics. J. Orthopedics. 25(11): 1301-1309.

36. Rai R, Yunos D.M., Boccaccini A.R., Knowles J.C., Barker I.A., Howdle S.M., Tredwell G.D., KeshavarzT.(2011)Poly-3-hydroxyoctanoate P(3HO), a medium chainlength polyhydroxyalkanoate homopolymer from Pseudomonas mendocina. J. Biomacromol. 12(6): 2126-36. 
37. Rentsch C, Rentsch B, Breier A, Hofmann A, Manthey S, Scharnweber D, Biewener A, Zwipp H. (2010). Evaluation of the osteogenic potential and vascularization of 3D poly(3)hydroxybutyrate scaffolds implanted subcutaneously in nude rats. J. Biomed. Mater. Res. 1: 185-95.

38. Reis E, Borges A, Fonseca C, Martinez M, Eleotério R, Morato G, Oliveira P. (2010). Biocompatibility, osteointegration, osteoconduction, and biodegradation of a hydroxyapatitepolyhydroxybutyrate composite. J. Brazil. Arch. of Bio. and Tech. 53: 817-826.

39. Schlickewei W, Schlickewei C. (2007) The use of bone substitutes in the treatment of bone defects-the clinical view and history. J. Macromol. Symp. 253: 10-23.

40. Schon R, Metzger M.C., Zizelmann C, Weyer N, Schmelzeisen R. (2006) Individually preformed titanium mesh implants for true-to-orginal repair of orbital fractures. Int. J. Oral. Maxillofac. Surg. 35: 990-995.

41. Volova T.G., Sevastianov V.I., Shishatskaya E.I. (2006) Polyhydroxyalkanoates - biodegradable polymers for medicine. Krasnoyarsk: Platina Publishers, $288 \mathrm{p}$.

42. Wang Y., Bian Yu-Zhu., Wu O., Chen Guo-Qiang. (2008) Evaluation of three-dimensional scaffolds prepared from poly(3-hydroxybutyrate-co-3-hydroxyhexanoate) for growth of allogeneic chondrocytes for cartilage repair in rabbits. J. Biomat.19: 2858-2868.

43. You M., Peng G., Li .J, Ma P., Wang Z., Shu W., Peng S., Chen G.Q. (2011) Chondrogenic differentiation of human bone marrow mesenchymal stem cells on polyhydroxyalkanoate (PHA) scaffolds coated with PHA granule binding protein PhaP fused with RGD peptide. J. Biomaterials. 32(9): 2305-13. 